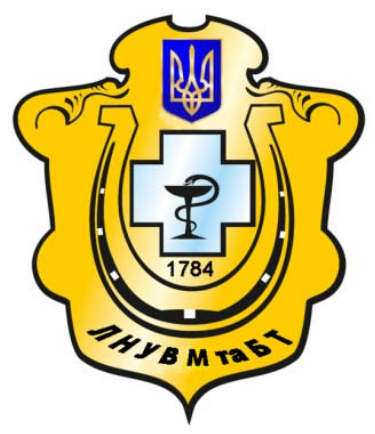

Науковий вісник Львівського національного університету ветеринарної медицини та біотехнологій імені С.3. Гжицького

Scientific Messenger of Lviv National University of Veterinary Medicine and Biotechnologies named after S.Z. Gzhytskyj

doi:10.15421/nvlvet7521

ISSN 2519-268X print

ISSN 2518-1327 online

$\underline{\text { http://nvlvet.com.ua/ }}$

УДК 637.5.05/07

\title{
Екстракт журавлини в технології варених ковбас з м'ясом водоплавної птиці
}

\author{
Н.В. Божко ${ }^{1}$, B.I. Тищенко ${ }^{1}$, В.М. Пасічний ${ }^{2}$ \\ natalybozhko@ukr.net, tischenko_1958@ukr.net, pasww1@ukr.net \\ ${ }^{1}$ Сумський національний аграрний університет, \\ вул. Г. Кондратьєва, 160, м. Суми, 40021, Украӥна; \\ ${ }^{2}$ Начіональний університет харчових технологій, \\ вул. Володимирська, 68, м. Київ, 01601, Україна
}

\begin{abstract}
Стаття присвячена дослідженню ефективності використання екстракту журавлини в технології м'ясомістких варених ковбас із м'ясом качки Пекінської та м'ясом індика механічного обвалювання. На сьогоднішньому етапі розвитку м'ясопереробної промисловості актуальним є питання пошуку альтернативних синтетичним, ефективних препаратів природного походження, що здатні уповільнювати окисні процеси і мають високу антиоксидантну активність. М'ясо водоплавної птиці є перспективною сировиною для м'ясної промисловості, але воно вирізняється високим вмістом ліпідів за рахунок фракиії моно- та поліненасичених жирних кислот, які чутливі до окиснення під впливом кисню повітря. Відомо, що таку властивість мають біофлавоноїди багатьох рослин, а також їх екстракти. У статті наведені результати дослідження впливу екстракту журавлини на перебіг окислювальних процесів у м'ясомісткій вареній ковбасі із м'ясом качки Пекінської та м'ясом птиці механічного обвалювання індичим з вмістом жиру понад 20\%. Екстракт журавлини додавали до фариу в кількості 0,01\%, 0,02\%, 0,03\% до маси фариу. Встановлено, що використання екстракту журавлини в технології м'ясомісткої вареної ковбаси дозволяє уповільнити перебіг окислювальних процесів. Найбільш ефективною концентрацією препарату виявився екстракт журавлини у кількості 0,02\%. Сенсорна оцінка показала, що внесення до складу рецептур екстракту журавлини не погіршило органолептичні показники продукту. Найбільш оптимальною за органолептичними показниками була м'ясомістка ковбаса варена Качина із додаванням 0,02\% екстракту журавлини.

Ключові слова: екстракт журавлини, м'ясо качки, м'ясомістка варена ковбаса, окислення ліпідів, антиоксиданти, кислотне число, перекісне число.
\end{abstract}

\section{Экстракт клюквы в технологии вареных колбас с мясом водоплавающей птицы}

\author{
Н.В. Божко ${ }^{1}$, В.І. Тищенко ${ }^{1}$, В.М. Пасичный ${ }^{2}$ \\ natalybozhko@ukr.net, tischenko_1958@ukr.net,pasww1@ukr.net \\ ${ }^{1}$ Сумской национальный аграрный университет, \\ ул. Г. Кондратьева, 160, г. Сумы, 40021, Украина; \\ ${ }^{2}$ Национальный университет пищевых технологий, \\ ул. Владимирская, 68, г. Киев, 01601, Украина
}

\begin{abstract}
Статья посвящена исследованию эффективности использования экстракта клюквы в технологии мясосодержащих вареных колбас с мясом утки Пекинской и мясом индюка механической обвалки. На сегодняшнем этапе развития мясоперерабатывающей промышленности является актуальным вопрос поиска альтернативных синтетическим, эффективных препаратов природного происхождения, способных замедлять окислительные процессы и имеющих высокую антиоксидантную активность. Мясо водоплавающей птицы является перспективным сырьем для мясной промышленности, но оно
\end{abstract}

Bozhko, N.V., Tischenko, V.I., Pasichniy, V.M. (2017). Cranberry extract in the technology of boiled sausages with meat waterfowl. Scientific Messenger LNUVMBT named after S.Z. Gzhytskyj, 19(75), 106-109. 
отличается высоким содержанием липидов за счет фракичи моно- и полиненасыщенных жирных кислот, которые чувствительны к окислению под воздействием кислорода воздуха. Известно, что таким свойством обладают биофлавоноиды многих растений, а также их экстракты. В статье приведены результаты исследования влияния экстракта клюквы на протекание окислительных процессов в мясосодержащей вареной колбасе с мясом утки Пекинской и мясом птиць механической обвалки индюка с содержанием жира выме 20\%. Экстракт клюквы добавляли к фаршу в количестве 0,01\%, 0,02\%, 0,03\% к массе фарша. Установлено, что использование экстракта клюквы в технологии мясосодержашей вареной колбасы позволяет замедлить протекание окислительных процессов. Наиболее эффективной концентрацией препарата оказался экстракт клюквы в количестве 0,02\%. Сенсорная оценка показала, что внесение в состав рецептур экстракта клюквы не ухудшило органолептические показатели продукта. Наиболее оптимальной по органолептическим показателям была мясосодержашчая колбаса вареная Утиная с добавлением 0,02\% экстракта клюквы.

Ключевые слова: экстракт клюквы, мясо утки, мясосодержащая вареная колбаса, окисление липидов, антиоксиданты, кислотное число, перекисное число.

\title{
Cranberry extract in the technology of boiled sausages with meat waterfowl
}

\author{
N.V. Bozhko', V.I. Tischenko', V.M. Pasichniy ${ }^{2}$ \\ natalybogko@yandex.ru, tischenko_1958@ukr.net,pasww1@ukr.net \\ ${ }^{1}$ Sumy National Agrarian University, \\ G. Kondratiev Str., 160, Sumy, 40021, Ukraine; \\ ${ }^{2}$ National University of Food Technologies, \\ Volodymyrska Str., 68, Kyiv, 01601, Ukraine
}

The article is devoted to the study of the efficacy of use of cranberry extract in the technology of meat-containing cooked sausages with Peking duck meat and Turkey meat mechanically separated. At the present stage of development of the meat industry is a topical issue of synthetic search for alternative, effective drugs of natural origin that can slow the oxidative processes and have a high antioxidant activity. Meat waterfowl is a promising raw material for the meat industry, but it has a high content of lipids at the expense of the fraction of mono - and polyunsaturated fatty acids, which are sensitive to oxidation under influence of air oxygen. It is known that have this property of bioflavonoids many plants and their extracts. The article presents the results of a study of the effect of cranberry extract on the occurrence of oxidative processes in meat-containing boiled sausages with meat Peking duck and poultry meat mechanically deboned Turkey with a fat content above 20\%. Cranberry extract was added to minced meat in the amount of $0.01 \%, 0.02 \%, 0.03 \%$ by weight of meat. It was found that the use of cranberry extract in the technology of cooked sausage meatcontaining can slow the occurrence of oxidative processes. The most effective concentration of the drug turned out was the cranberry extract in an amount of $0.02 \%$. The sensory evaluation showed that the addition of cranberry extract did not worsen the organoleptic characteristics of the product. The optimal organoleptic characteristics were meat-containing sausage boiled Duck with the addition of $0.02 \%$ cranberry extract.

Key words: cranberry extract, meat ducks, meat-containing cooked sausage, lipid oxidation, antioxidants, acid number, peroxide number.

\section{Вступ}

М'ясо качки Пекінської вирізняється високим вмістом ліпідів за рахунок фракції моно- та поліненасичених жирних кислот (ПНЖК), які чутливі до окиснення під впливом кисню повітря. Це ускладнює виробництво ковбасних та інших виробів 3 цього виду сировини, тому що може спричинити погіршення їхніх сенсорних властивостей через виникнення сполук, які можуть спричиняти утворення прогірклого смаку і запаху, негативно вплинути на харчову цінність продуктів через втрату вітамінів та незамінних ненасичених жирних кислот (Pasichnyi and Zheludenko, 2014).

На сьогоднішньому етапі розвитку м'ясопереробної промисловості є актуальним питання пошуку альтернативних синтетичним, ефективних препаратів природного походження, що здатні уповільнювати окисні процеси і мають високу антиоксидантну активність. Відомо, що таку властивість мають біофлавоноїди багатьох рослин, а також їх екстракти (Topchii et al., 2014).

Метою роботи було дослідження ефективності використання екстракту журавлини як антиоксиданту в технології м'ясомісткої вареної ковбаси 3 м'яса кач- ки Пекінської та м'яса птиці механічного обвалювання (МПМО) з індичатини.

\section{Матеріал і методи досліджень}

Як дослідні зразки використовували м'ясомістку ковбасу «Качину» із вмістом жиру понад 20\% (Bozhko et al., 2016).

Як антиокислювальний препарат використовували екстракт журавлини (Україна). До дослідних зразків ковбаси на стадії приготування фаршу додавали екстракт журавлини в трьох концентраціях: 0,01\%, $0,02 \%, 0,03 \%$ до маси сировини, контролем слугував зразок ковбаси без додавання антиоксидантного препарату. Зберігали модельні зразки при температурі $4{ }^{\circ} \mathrm{C}$ впродовж 5 діб. Контрольованими показниками були кислотне (КЧ) та пероксидне (ПЧ) числа, які визначали через 1, 3 та 5 діб зберігання (Antipova et al., 2001).

\section{Результати та їх обговорення}

Результати дослідження динаміки кислотного числа дослідних зразків ковбас в процесі зберігання подано на рис. 1. 


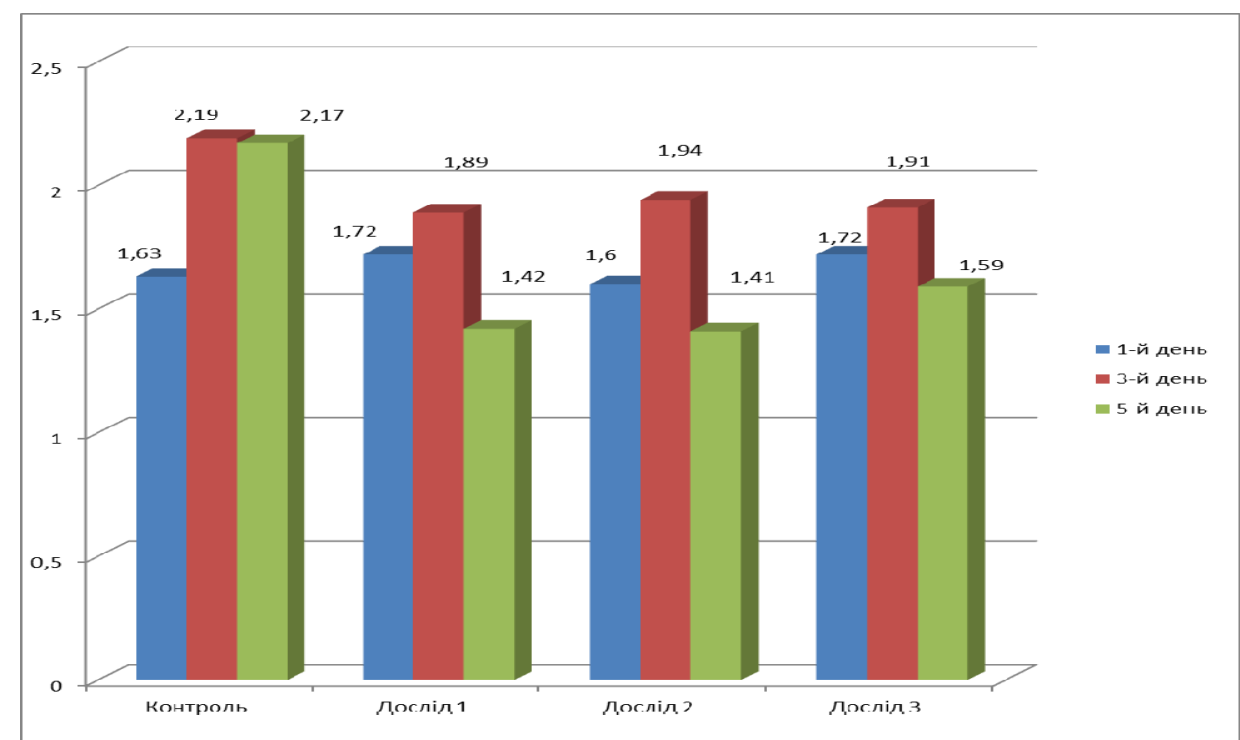

Рис. 1. Значення кислотного числа дослідних зразків ковбас в процесі зберігання, мг КОН

Аналіз зміни кислотного числа показує, що додавання до фаршу екстракту журавлини пригнічує процес гідролізу ліпідів під час зберігання. Так, показник кислотного числа на 3 добу зберігання в дослідних зразках відповідно до рецептур 1, 2 і 3 з внесенням відповідно $0,1 \%, 0,2 \%$ і $0,3 \%$ екстракту журавлини був менший в середньому на $14 \%$. Наприкінці експерименту найменше кислотне число спостерігалося у зразку з концентрацією антиокислювальної добавки
$0,02 \%$, його значення становило 1,41 мг КОН, тимчасом як в контролі цей показник сягнув 2,2 .

Таким чином, гідролітичні процеси в тригліцеридах упродовж досліджуваного періоду не $є$ інтенсивними. Отримані залежності пояснюються здатністю біофлавоноїдів екстракту журавлини уповільнювати гідроліз жирних кислот фаршу.

Результати дослідження динаміки перекісного числа готового продукту в процесі зберігання готових ковбасних виробів подані на рис. 2.

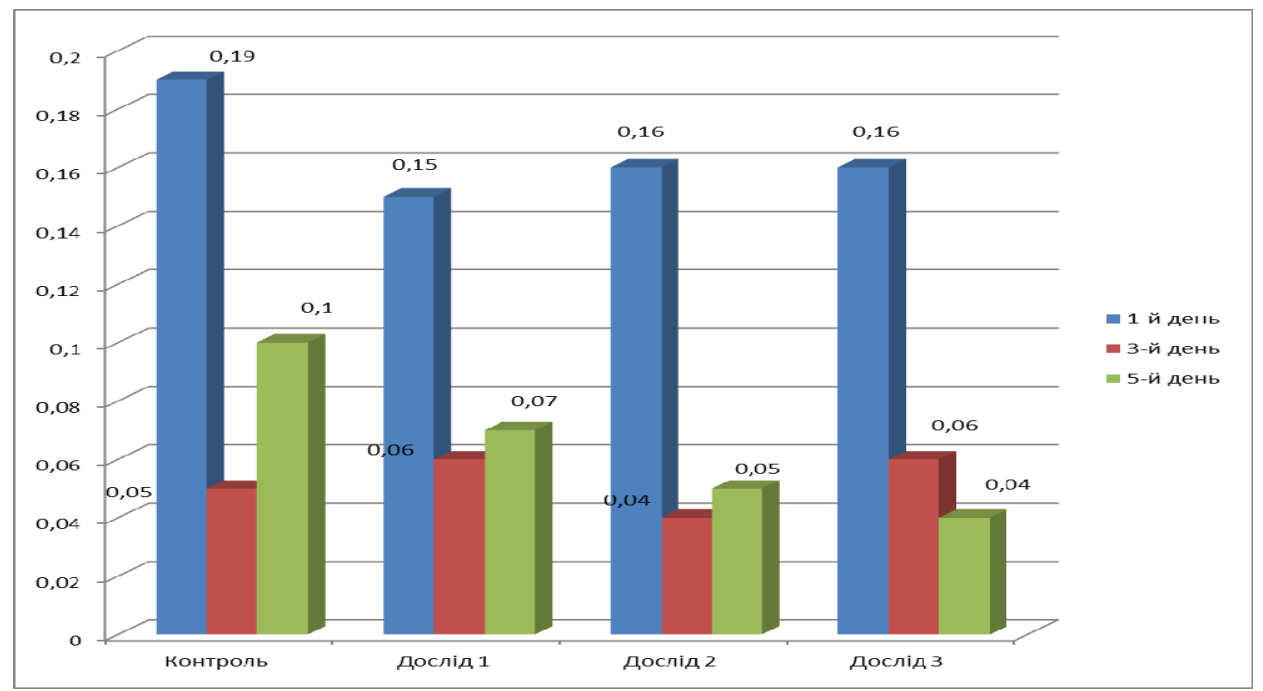

Рис. 2. Значення перекісного числа дослідних зразків ковбас в процесі зберігання, J\%

Отримані результати показали, що серед дослідних зразків фаршу ковбас перекісне число інтенсивніше зростало у контрольному зразку, а екстракт журавлини у всіх трьох концентраціях сповільнював окисні процеси. Найбільшу стабілізуючу дію мав екстракт журавлини в концентрації $0,03 \%$ : перекісне число в цьому зразку в кінці досліджуваного терміну дорівнювало $0,04 \% \mathrm{~J}_{2}$, тимчасом як в контролі цей показник становив $0,10 \% \mathrm{~J}_{2}$, що більше ніж в два рази.
Актуальним питанням застосування біопрепаратів природного походження антиокислювальної дії $\epsilon$ їхній вплив на органолептичні показники продукту, адже більшість біофлавоноїдів мають виражене забарвлення різних відтінків. Результати сенсорної оцінки виготовлених ковбас 3 м'ясом качки Пекінської i МПМО подано на рис. 3. 


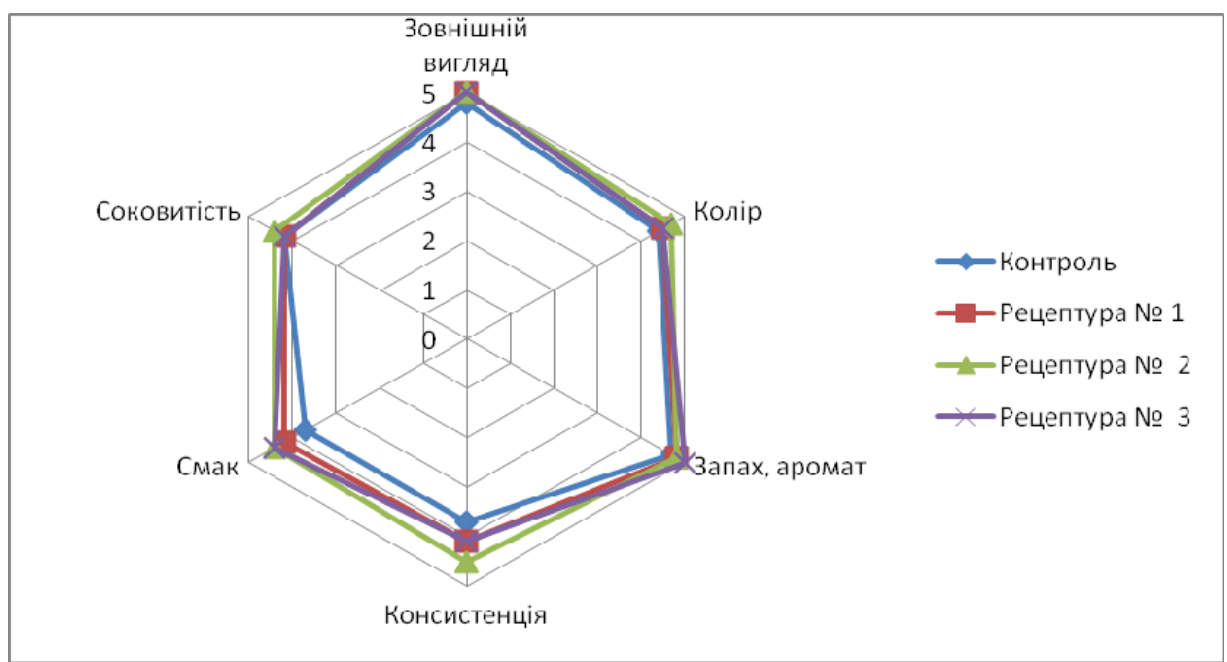

Рис. 3. Сенсорна характеристика дослідних зразків.

Дані діаграми сенсорних показників ковбас з різним вмістом екстракту журавлини свідчать про те, що всі зразки ковбас із антиоксидантами відповідають вимогам стандарту за органолептичними показниками.

Варто зазначити, що всі зразки досліджуваних варених ковбас отримали вищі оцінки порівняно 3 контрольним зразком. Зразки № 1-3 характеризувались приємним запахом, мали гарні смакові властивості та пружну консистенцію. Високу органолептичну оцінку отримали всі показники якості мясомістких варених ковбас із м'ясом качки Пекінської та МПМО індичого, проте найвищу оцінку отримав зразок № 2.

\section{Висновки}

Використання екстракту журавлини в технології мясомісткої вареної ковбаси дозволяє уповільнити перебіг окислювальних процесів. Найбільш ефективною концентрацією препарату виявився екстракт журавлини у кількості $0,02 \%$. Сенсорна оцінка показала, що додавання екстракту журавлини в кількості $0,1-0,3 \%$ не погіршує органолептичні показники варених ковбас. Найбільш оптимальною за органолептичними показниками була м'ясомістка ковбаса варена Качина із додаванням $0,02 \%$ екстракту журавлини.

Перспективи подальших досліджень. Результати досліджень підтверджують перспективність використання екстракту журавлини в технології м'ясомістких варених ковбас $з$ м'ясом водоплавної птиці. Подальші дослідження будуть спрямовані на визначення впливу екстракту журавлини на мікробіологічну стабільність виготовленого продукту.

\section{Бібліографічні посилання}

Pasichnyi, V.M., Zheludenko, Yu.V. (2014). Perspektyva naturalnykh antyoksydantiv dlia vykorystannia $\mathrm{v}$ miasopererobnii haluzi. Zbirnyk naukovykh prats KhDUKhT. Kharkiv: KhDUKhT, 264-276 (in Ukrainian).

Topchii, O.A., Pashchenko, O.V., Kotliar, Ye.O. (2014). Vykorystannia pryrodnoho antyoksydantu u vyrobnytstvi sichenykh napivfabrykativ. Materialy mizhn. nauk. konf: «Novi idei v kharchovii nautsi novi produkty kharchovii promyslovosti» (13-17 zhovtnia 2014 roku). Kyiv: NUKhT, 210 (in Ukrainian).

Bozhko, N.V., Pasichnyi, V.M., Bordunova, V.V. (2016). Miasovmistki vareni kovbasy z vykorystanniam miasa kachky. Naukovyi visnyi LNUVMBT im. S.Z.Hzhytskoho. Seriia «Kharchovi tekhnolohii». 18, 2(68), 143-147. doi:10.15421/nvlvet6829 (in Ukrainian).

Antipova, L.V., Glotova, I.A., Rogov, I.A. (2001). Metody issledovanija mjasa i mjasnyh produktov. M.: Kolos (in Russian).

Стаття надійшла до редакиї 7.03.2017 